\title{
Římskoprávní kořeny zákonodárství krále Kentu Æthelberhta
}

\author{
Marie Šmejkalová
}

Univerzita Karlova, Právnická fakulta

Kontaktnie-mail: marie.smejkalova98@gmail.com

\section{Roman Law Roots of Kentish King Athelberht's Legislation}

\begin{abstract}
:
The article focuses on the Æthelberht's Law Code from the beginning of the seventh century as it aims to analyse Roman law roots of Æthelberht's legislation. A wide range of primary and secondary sources (both domestic and foreign) is used for the analysis. The introductory part of the paper provides broader historical context with an emphasis on king Æthelberht himself as well as on a description of his law code. Furthermore, the work analyses the Roman law roots of the Code by not only using The Digest of Justinian, The Institutes of Justinian but also the first known written source of Roman law - Lex Duodecim Tabularum. Additionally, a comparison of Frankish Lex Salica and Æthelberht's Code is presented. The author aims to prove that the Anglo-Saxon law codes were, in fact, influenced by the Roman law.
\end{abstract}

Key words: Anglo-Saxon history; jurisprudential reception; Æthelberht's Code; Æthelberht (c. 550-616); early medieval law

Klíčová slova: anglosaské dějiny; recepce v právu; Æthelberhtův zákoník; Æthelberht (c. 550-616); právo v raném středověku

DOI: $10.14712 / 2464689 X .2021 .33$ 
Qui inter cetera bona, quce genti suce consulendo conferebat, etiam decreta illi judiciorum, juxta exempla Romanorum, cum consilio sapientium constituit; quae conscripta Anglorum sermone hactenus habentur, et observantur $a b$ ea, ${ }^{1}$ napsal ve svém díle Církevní dějiny národa Anglů Beda Ctihodný. Právě jeho citát vytyčuje směřování tohoto článku, jelikož jeho autor zdůrazňuje, že král Æthelberht za svého života vydal staroanglicky psaná soudní nařízení podle římských vzorů2 ${ }^{2}$ juxta exempla Romanorum.

Na úvod je na místě uvést definici recepce práva. Podle názoru D. Falady se dá recepce v právní nauce rozdělit do tř̌́ skupin: „recepce jako přejímání práva, tedy jako převzetí celého právního řádu“; ${ }^{3}$ „recepce jako přejímání práva [...] převzetí základních parametrů struktury právního řádu“4 $\mathrm{a} v$ neposlední řadě pak „,recepce jako inspirace“.5

Hlavním záměrem článku je tedy v souladu s výše zmíněným citátem Bedy Ctihodného snaha o identifikaci ř́mskoprávních kořenů zákoníku krále Æthelberhta. Materie, jež se $\mathrm{k}$ tomuto tématu vztahuje, je vskutku obsáhlá, a $\mathrm{z}$ toho důvodu se jedná pouze o prưřezovou studii, která využívá pouze některých odpovídajících článkủ z kodexů a zákoníků napříč římským právem, počínaje Lex Duodecim Tabularum, až po slavný Justiniánův Corpus Iuris Civilis.

Cílem článku není detailně popsat všechna sobě navzájem podobná ustanovení ze všech dob vývoje římského práva. Záměrem je spíše snaha čtenáři oblast rané recepce římského práva v Británii přiblí̌̌it, či dokonce podnítit určitou míru zvědavosti se na spojení mezi těmito dvěma právními systémy zaměřit.

\section{Historický kontext}

Pro pochopení vlivu římského práva na zákoník krále Æthelberhta je bezpochyby žádoucí vymezit širši historický rámec osvětlující vztah obou prostředí, jehož kořeny lze nalézt již v Caesarových výbojích na Britské ostrovy kolem roku 55 př. n. 1. Británie byla pro římskou říši lákavým soustem, ale dobýt se ji podařilo až v roce $47 \mathrm{n}$. 1., po čtyřech letech intenzivních snah vojska vyslaného z rozkazu císaře Claudia. ${ }^{6}$ Po úspěšné invazi se jižní část ostrova stala římskou provincií, jejíž správu vykonávali římští správci, kterými se stávali „významní rímští politici, zejména bývalí konzulové“.7

Pro kontext tohoto článku se jako zcela zásadní jeví působení tř́ z nejvýznamnějších ř́mských právníků, Papiniana, Ulpiana a Paula, v Británii. Všichni tr̆i v roce 207 doprovázeli při cestě do Británie císaře Septima Severa, načež se záhy po jejich př́ijezdu Papinianus stal de facto předsedou soudu v Yorku, přičemž jako jeho další soudci působili i Paulus a Ulpianus. Jak podotýká Charles P. Sherman, dala by se taková situace přirovnat k tomu, že by se Nejvyšší soud Spojených států amerických nacházel na Aljašce. ${ }^{8}$

1 GILES, J. A. The Complete Works of Venerable Bede, in the original Latin, collated with the Manuscripts, and various printed editions, and accompanied by a new English translation of the Historical Works, and a Life of the Author. London: Whittaker and Co., 1843, s. 188.

2 VENERABILIS, B. Církevni dějiny národa Anglů. Praha: Argo, 2008, s. 101.

3 FALADA, D. Recepce ř́mského práva. Plzeň: Vydavatelství a nakladatelství Aleš Čeněk, 2016, s. 11.

4 Tamtéž, s. 16.

5 Tamtéž, s. 19.

6 SCRUTTON, T. E. Influence of the Roman Law on the Law of England: Being the Yorke Prize Essay of the University of Cambridge for the Year 1884. Cambridge: Cambridge University Press, 1885, s. 3.

$7 \quad$ KUKLÍK, J. - SELTENREICH, R. Dějiny angloamerického práva. Praha: Linde, 2007.

8 SHERMAN, Ch. P. The Romanization of English Law. Yale Law Journal, 1914, Vol. 23, No. 4, s. 318. 
Ř́mské legie provincii opustily až v roce 410 , tedy po téměř čtyřech stoletích. K poslednímu století jejich prrítomnosti lze podle anglického soudce Thomase Edwarda Scruttona konstatovat, že vliv Římské rríše na dění na ostrově byl mizivý. ${ }^{9}$ Tentýž autor však poznamenává, že s odchodem rrímských legií vliv impéria na právní kulturu nebyl ukončen jako mávnutím kouzelného proutku, nicméně postupně došlo $\mathrm{k}$ splynutí římského práva se zvykovým právem původních britských kmenů a posléze též s právem barbarských kmenů, které na ostrov ustavičně útočily. A právě na základě této kombinace právních systémů podle Scruttona vzniklo prostředí pro vznik Æthelberhtova zákoníku. ${ }^{10}$

Druhým zásadním předělem byla misie převora Augustina, který je dnes známý jako sv. Augustin z Canterbury, který byl do Británie vyslán papežem Řehořem I. Velikým, aby se pokusil o christianizaci tamějších pohanských vládců. Na tomto místě je zásadní zmínit, že se bavíme o konci 6 . století, misie byla papežem vyslána roku 596. ${ }^{11}$ Toto časové vymezení je důležité uvést proto, že v této době již byla sepsána sbírka dnes označovaná jako Corpus Iuris Civilis, jež byla ve své době Justiniánem nazývána tria volumina. Dokonce jde o období více než třicet let po smrti císaře Justiniána. Jak podotýká Edward D. Re, papež Řehoř I. byl vzdělaný muž, který byl seznámen s justiniánskými kodifikacemi a tuto znalost předal také Augustinovi. ${ }^{12}$ Když se čtyřiceti benediktinskými mnichy dorazil převor do Británie, dostal se i se svou družinou do Canterbury, kde vybudovali klášter, a od krále Æthelberhta dostal Augustin svolení, aby spolu se svými mnichy šíril víru v celém kentském království. ${ }^{13}$ Ač by se na první pohled mohla tato ochota ze strany pohanského krále zdát opravdu nezvyklá, lze ji snadno objasnit znalostí podmínky, pod kterou bylo Æthelberhtovi umožněno oženit se s franckou princeznou Bertou. Podle Bedy Ctihodného ji Æthelberht mohl pojmout za manželku pouze za předpokladu, že jí umožní volně praktikovat křest’anství. ${ }^{14}$

Edward D. Re dále zdůrazňuje, že Augustin přinesl do Británie koncept vlády, který tehdejší kmenové organizace neznaly, zároveň obyvatelům ostrova představil organizaci veřejné správy či výběru daní podle římského vzoru - došlo k rozdělení území na tzv. hides, jednoduše řečeno na obdobně velké části země, ze kterých se odváděla daň. Na okraj stojí za zmínku, že římské právo v Británii existovalo tak dlouho, dokud tam žili Romani, v době prevevádající personality práva mezi ně patřili právě kněží, kteří na Řehořův rozkaz na ostrov zamírili. Přesto ale docházelo $\mathrm{k}$ vulgarizaci ř́mského práva, a to zejména proto, že obyvatelé Británie neovládali klasickou latinu, ř́mskoprávní koncepty ale i přesto přetrvaly. ${ }^{15}$

Lze ale spekulovat o tom, zda se např́íklad do Británie přenesl rozdíl ve významu slova servus, který se v antické latině používal pro označení otroka, avšak v latině středověké už označuje i sluhu. V Æthelberhtově zákoníku se nalézají články jak o otrocích, tak o sluzích. Záleží zde asi na interpretaci, jestli již mohlo jít o změnu ve významu, či jestli se mělo jednat o dvě rozličné skupiny osob. ${ }^{16}$

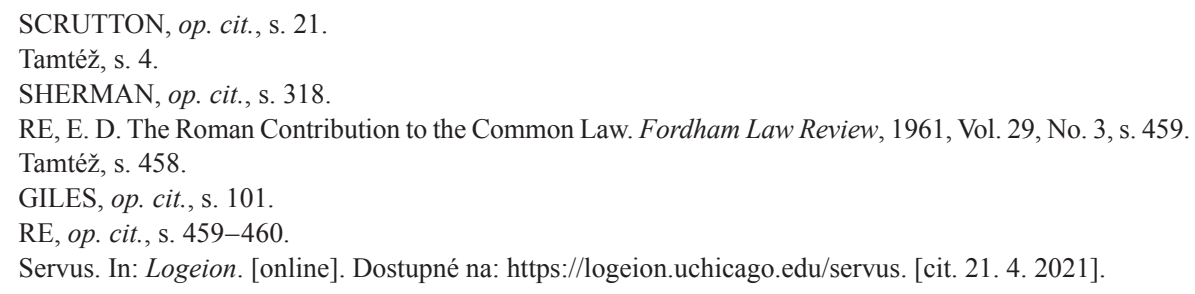




\section{Osobnost krále Kentu Æthelberhta a jeho zákoník}

Pro pochopení pohnutek, které vedly $\mathrm{k}$ vytvoření zákoníku, jemuž se tento článek převážně věnuje, je podstatné si v krátkosti představit i osobnost krále Æthelberhta. Byl to totiž právě on, kdo na ostrově zavedl tradici zápisu práva. ${ }^{17}$ Zároveň byl podle Bedy Ctihodného prvním králem Anglů, který vstoupil do království nebeského. ${ }^{18}$ Bohužel, o Æthelberhtovi dodnes není mnoho známo, přeci jen vládl nejspíše mezi lety 589 a 616, a většina zpráv, která se o něm dochovala pochází právě od Bedy Ctihodného, a nedají se tedy s jistotou považovat za informace historicky přesné. ${ }^{19}$ Nelze ovšem zpochybnit, že byl tím panovníkem, který se zasadil o vytvoření jednoho z prvních zákoníků, který nebyl napsán latinsky, nýbrž př́slušným germánským jazykem. ${ }^{20}$

Když se budeme držet informací, které poskytuje Beda Ctihodný, dozvíme se, že král Augustinovi a jeho doprovodu po jejich př́ijezdu nakázal zůstat na ostrově Thenet, na kterém přistáli, a rozhodl se je osobně navštívit. Nejspiše kvůli určité ,starověké podezřívavosti nakázal, aby $\mathrm{k}$ němu byli přivedeni na venkovním prostranství, kdyby snad uvnitř budovy provozovali magii“ , 21 oni ovšem dorazili pouze se stř́brným křǐžem a obrazem Ježíše Krista. Po rozpravě jim, jak již bylo uvedeno výše, umožnil volně šiřit víru a zároveň se usídlit v Canterbury. 22

O tom, kdy přesně a za jakých podmínek byl král Æthelberht pokřtěn, panují spory. Podle Andrew Kirbyho k tomu mohlo dojít kdykoliv mezi lety 597 a 601, podle papeže to ale i tak bylo př́liš pozdě, a dokonce napsal rozladěný dopis královně Bertě, že se jí nepodařilo jejího manžela ke křtu přimět dř́ive. ${ }^{23}$

Předtím, než se článek zaměří na samotnou analýzu římskoprávních kořenů Æthelberhtova zákoníku, považuji za důležité zákoník popsat. Přestože se jedná o právní památku z počátku sedmého století našeho letopočtu, zápis, který se dochoval, je pozdější, až z dvanáctého století. Tzv. Textus Roffensis shromažd’uje všechny rané anglosaské zákony, počínaje právě Æthelberhtovým zákoníkem, ale zároveň i kopiáře, které úzce souvisely $\mathrm{s}$ rochesterským opatstvím. Autor zůstává neznámý, nicméně zásluhy se připisují biskupu Anselmu z Canterbury, s jehož působením v úřadu se doba vzniku dokumentu překrývá. ${ }^{24}$

Zákoník je členěn na 83 článků, kterým předchází následující předmluva: „Toto jsou výnosy, které král Æthelberht vydal v čase převora Augustina““.25, 26 Už tato uvozující klauzule naznačuje, že křest’anství mělo na vznik zákoníku nepominutelný vliv.

\footnotetext{
17 RE, op. cit., s. 460.

18 SIMPSON, A. W. B. The Laws of Ethelbert. In: On the Laws and Customs of England: Essays in Honor of Samuel E. Thorne (Studies in Legal History). New York City: Chapel Hill, 1981, s. 38.

19 Tamtéž.

20 Tamtéž, s. 39.

21 GILES, op. cit., s. 103

22 Tamtéž.

23 KIRBY, A. - PETERS, L. The Earliest English Kings. Milton Park: Taylor \& Francis, 2000, s. 28.

24 RICHARDS, M. P. Texts and Their Traditions in the Medieval Library of Rochester Cathedral Priory. [online]. Philadelphia: Library of Congress Catalog, 1988, s. 43. Dostupné na: https://www.jstor.org/stable /1006485. [cit. 17. 3. 2021].

25 Æthelberht's code (Abt). Early English Laws. [online]. Dostupné na: https://earlyenglishlaws.ac.uk/laws /texts/abt/view/\#edition-77/translation. [cit. 2021-03-17].

26 Není-li výslovně uvedeno jinak, jsou všechny použité překlady autorské.
} 
Jedná se o kazuistický zákoník, v praxi jsou všechny články výčtem přesně popsaných deliktů, a finančních kompenzací, které za spáchání následují. Největší pozornost je věnována ublížení na těle, zabývá se jím přesně 56 článků. V této souvislosti se není možné vyvarovat definici tzv. wergeldu, jenž ,byl přidělován každému muži ... tj. cena, která se musela zaplatit, byl-li zabit, jeho rodině a která mimoto byla také penízem, jejž on sám musel platit králi, aby si vykoupil, dopustil-li se hrdelního činu, svůj život“". ${ }^{27}$ Toto vykoupení mělo také, mimo jiné, přecházet krevní mstě, druhou alternativou totiž bylo ono př́íslovečné „oko za oko, zub za zub“.28

Je třeba uvést, že výše wergeldu se lišila, ,byla odstupňována podle společenského postavení oběti““. ${ }^{29}$ Tento fenomén lze velmi dobře pozorovat i v Æthelberhtově zákoníku, liší se naprŕíklad cena za zabití svobodného muže (50 šilinků králi), za zabití osvobozeného otroka (zde docházelo ještě k odlišení otroků prvního, druhého a třetího řádu, a wergeld činil 80, 60, respektive 40 šilinků) či za zabití domácího sluhy (6 šilinků). ${ }^{30}$

\section{Římskoprávní kořeny vybraných ustanovení}

Identifikace římskoprávních kořenů Æthelberhtova zákoníku se v průběhu psaní tohoto článku ukázala jako relativně složitá, přesto jsem se o ni však pokusila. V následující části tak postupuji chronologicky za užití některých pramenů římského práva - Lex Duodecim Tabularum, Codex Theodosianus a v neposlední řadě justiniánský Corpus Iuris Civilis, zejména tedy Instituce a Digesta.

\section{Lex Duodecim Tabularum}

Zákoník dvanácti desek se ukázal jako velmi nápomocný, podařilo se mi totiž identifikovat některá bud' shodná, anebo minimálně podobná ustanovení. Zcela obecně, Æthelberhtův zákoník hovoří obsáhle o náhradě škody (at' už se jedná o krádež, ublížení na zdraví či vraždu), a nezařaditelný 7 . fragment antického zákoníku stanovuje, ,že v zákonech je osm druhů trestů: náhrada škody, vězení, bičování, soukromá msta, nečestnost, vyhnanství, smrt, otroctví“. ${ }^{31}$ Náhrada škody obsažená v Æthelberhtově zákoníku je tak uváděna i zde. Za povšimnutí ovšem stojí i zmínka o soukromé mstě. Ta se v Æthelberhtově zákoníku nenachází a domnívám se, že její náhradou měl být již zmiňovaný wergeld.

Pokud se ovšem zaměřime na kompenzace za fyzické zranění konkrétněji, protože, jak již bylo specifikováno, této oblasti se věnuje většina Æthelberhtova zákoníku, je na ně možno narazit i v Zákoníku dvanácti desek. Na desce osmé jsou rovnou tři fragmenty, které se zdají být velmi podobné fragmentům z kentského zákoníku. Nejprve se jedná o fragment 2.: „Jestliže zničí končetinu a nedohodne se s ním, at' sáhne k odvetě.“32 Toto ustanovení se Æthelberhtovu zákoníku mírně vymyká, protože Lex Duodecim Tabularum

27 MAUROIS, A. Historie Anglie. Praha: Julius Albert, 1945, s. 38.

28 ELSTER, J. Closing the Books: Transitional Justice in Historical Perspective. [online]. Cambridge: Cambridge University Press, 2004, s. 166. Dostupné na: https://doi.org/10.1017/CBO9780511607011. [cit. 2. 4. 2021].

29 SCHELLE, K. - KADLECOVÁ, M. - VESELÁ, R. - VLČEK, E. - VOJÁČEK, L. - ŽIDLICKÁ, M. Právní dějiny. Plzeň: Vydavatelství a nakladatelství Aleš Čeněk, 2007, s. 390.

30 Æthelberht's code (Abt), op. cit.

31 SKŘEJPEK, M. Lex et ius: zákony a právo antického Říma. Plzeň: Vydavatelství a nakladatelství Aleš Čeněk, 2018, s. 43.

32 Tamtéž, s. 34. 
ještě připouštěl soukromou mstu, zatímco kentský zákoník již nikoliv. Ovšem fragment 4. uvádí: „Způsobí-li př́íkoří (druhému), at’ je pokutou dvacet pět.“,33 a fragment 5.: „...Zlomení...potrestá." ${ }^{34}$ Fragment 4. sice nespecifikuje, o jaká přesně příkoří by se mělo jednat, avšak je zřetelné, že toto utrpení má být vykoupeno určitou pokutou, což se prolíná téměř do všech článků kentského zákoníku. U fragmentu 5. lze pozorovat nejlépe odpovídající ustanovení článku 36a. Æthelberhtova zákoníku, který hovoří o způsobení fraktury lebky a (finančním) trestu za něj, dále pak článku 52, který se věnuje zlomenině paže, článku 65, jenž se zabývá zlomeninou stehenní kosti, a článku 66, který obsahuje kompenzaci za zlomeninu žebra. ${ }^{35} \mathrm{~V}$ této souvislosti stojí za zmínku také to, že čtvrtá kniha justiniánských Institucí poukazuje na následující: „praetoři povolili uraženým, aby to sami ocenili, takže soudce odsoudil bud' na tolik, na kolik se uražený ocenil, anebo na méně, a to podle toho, jak se mu to zdálo spravedlivé“، ${ }^{36} \mathrm{~V}$ dobách pozdějších se tak již neužívalo odstupňování podle Zákoníku dvanácti desek, nicméně záleželo na uvážení soudce, jak vysokou pokutu se rozhodne udělit.

Ač není možné nalézt doslovně odpovídající ustanovení v obou porovnávaných pramenech, je velmi dobře pozorovatelné, že kompenzace, o kterých se hovoří i v Æthelberhtově zákoníku, byly zmíněny již v Lex Duodecim Tabularum. Naopak institut krevní (či osobní) msty, se vyskytuje pouze ve starším ze zákoníků.

V Lex Duodecim Tabularum se při bližším pohledu nachází také zmínka o kompenzacích v podobě násobků, jde ale pouze o kusé zmínky. Např́íklad podle fragmentu 15a. je „za ukrývanou a podstrčenou krádež ... pokutou trojnásobek“.37 Odpovídajícím ustanovením Æthelberhtova zákoníku by mohl být článek 10: „Pokud svobodný muž něco ukradne králi, zaplatí devítinásobek “ 38 v tomto př́padě se ale opravdu jedná o velmi vzdálenou podobnost. Domnívám se, že by mohlo jít pouze o inspiraci institutem náhrady určitým násobkem hodnoty poškozené, resp. ukradené věci.

\section{Digesta seu Pandactae}

Při hledání odpovídajících ustanovení v justiniánských Digestech lze relativně rychle zjistit, že římské právo v době císaře Justiniána nepracuje s cenou tzv. ,za hlavu“, tedy že kompenzaci za vraždu či zabití bychom hledali marně. Jak se uvádí výše, pokud nebylo podle Lex Duodecim Tabularum dosaženo dohody mezi poškozenou stranou a tím, kdo poškození způsobil, přistoupilo se k odvetě, pro niž se užíval latinský termín talio. ${ }^{39} \mathrm{Od}$ odvety se ovšem postupem času upouštělo.

Ač by se jevilo pravděpodobné, že ustanovení podobná kentskému zákoníku by se mohla nacházet v knize čtyřicáté osmé Digest, konkrétně v devatenáctém titulu, jenž nese název De poenis - O trestech, není tomu tak a tresty uvedené v Digestech se nezabývají

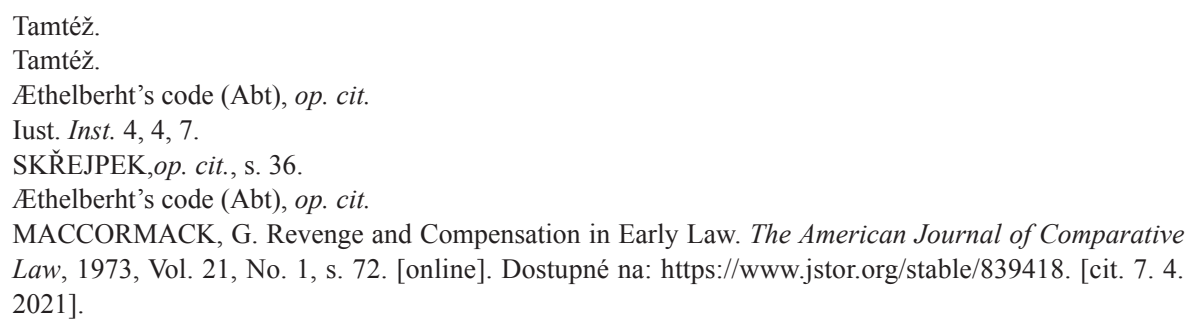


pokutami za přečiny, naopak hovoří např́iklad o vyhnanství či o práci v dolech. Toto lze demonstrovat např́iklad na čtvrtém fragmentu, podle Marciana: „ti, kdož byli vyhnáni, stejně jako ti, jež byli deportováni na ostrovy, musí pobývat mimo zakázaná místa“ ${ }^{40}$ a dále pak na osmém fragmentu, Ulpianus totiž rríká: „existuje trest, jenž odebírá svobodu, takovým trestem může být, např́iklad, odsouzení do dolů““. ${ }^{41}$

Lze tedy uzavřít, že v Digestech se podobné tresty, jaké bychom nalezli v Æthelberhtově zákoníku, nenachází. Nicméně, jak bude záhy demonstrováno v další části tohoto článku, pokutám, a zejména kompenzacím, se věnují justiniánské Instituce.

\section{Iustiniani Institutiones}

Ve čtvrté knize Institucí narazíme na zmínku o pokutě za krádež spáchanou jednak otrokem, jednak svobodným člověkem. Tato pokuta je podle 5. fragmentu 1. titulu stanovena na čtyřnásobek, pokud se jedná o krádež zjevnou, zatímco na dvojnásobek, jde-li o krádež nezjevnou. ${ }^{42}$ Odpovídajícím článkem v Æthelberhtově zákoníku by mohl být např́iklad článek 28, zejména jeho rozvíjející část a.: „28) Pokud se svobodný muž vloupá do ohrazeného pozemku, zaplatí 6 šilinků, a. Pokud tam člověk zabere majetek, zaplatí trojnásobek jako kompenzaci“ ${ }^{43}$ a dále pak článek poslední, který specifikuje, že ,,pokud otrok krade, zaplatí dvojnásobek jako kompenzaci““. ${ }^{4}$

Jak je uvedeno výše, podle Institucí činila pokuta za krádež nezjevnou právě, i v Æthelberhtově zákoníku zmiňovaný, dvojnásobek. Lze se tedy domnívat, že kompenzace v podobě násobků byla skutečně $\mathrm{v}$ Æthelberhtově zákoníku inspirována římským právem. Další kapitola tohoto článku uvádí, že zákoník pak pracuje i s přesně stanovenými pokutami za zločiny otroků, což je ale institut, který by bylo možno nalézt v germánském spíše než rímském právu.

Pokud se ovšem věnujeme trestnímu právu, není možné přehlížet ani Aquiliův zákon, třetí titul čtvrté knihy Institucí uvádí následující: „,en, kdo protiprávně usmrtí cizího otroka [...] bude odsouzen, aby vlastníkovi zaplatil tolik, jaká byla nejvyšší hodnota věci v daném roce“. ${ }^{45}$ Æthelberhtův zákoník se vraždě otroka de facto nevěnuje, ošetřuje pouze vraždu osvobozeného otroka, kde je opět podle řádu osvobozence stanoveno, jaká bude finanční kompenzace za jeho vraždu. Co je ovšem kompenzováno stejnou cenou, jako by byl otrok samotný zabit, je podle článku 80 následující čin: „pokud je sluhovo oko vypíchnuto či noha useknuta, zaplatí jeho pánovi celou cenu“.46

Čemu se Instituce věnují relativně ze široka, je institut kompenzací v podobě násobků. Podle čtvrtého titulu však ale ,všechny žaloby zní bud' na jednonásobek, nebo na dvojnásobek, nebo na trojnásobek, nebo na čtyřnásobek, na více nezní ani jedna žaloba“. ${ }^{47}$

Po srovnání podobných kompenzací jsem zjistila, že se kromě již výše zmiňovaného dvojnásobku za nezjevnou krádež př́íliš neshodují. Æthelberhtův zákoník se zabývá

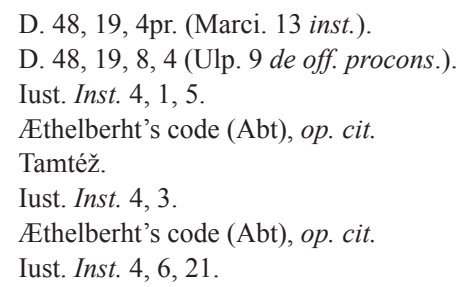


kompenzacemi například v případě, že ,svobodný muž okrade svobodného muže“48 (článek 15), či když „,král popíjí v něčím domově a tento člověk udělá něco velmi neuctivého“49 (článek 9). V prvním zmíněném případě jde o kompenzaci ve výši trojnásobku a v druhém dvojnásobku. Rozhodně se ale nejedná o tak pregnantně vymezené oblasti kompenzací, jako je tomu v 21. až 26. fragmentu čtvrtého titulu justiniánských Institucí.

V Æthelberhtově zákoníku se ovšem vyskytují i kompenzace na devíti, jedenácti, či dokonce dvanáctinásobek. Lze je nalézt $\mathrm{v}$ jednom článku týkajícím se krádeží králova majetku (článek 10) a poté hlavně v ustanoveních týkajících se zločinů, které by se nejlépe daly popsat jako proti náboženství, nebot’ dvanáctinásobkem má být kompenzován „majetek Boha a církve“, 50 jedenáctinásobkem pak „majetek biskupư “51 a devítinásobkem „majetek kněze“. ${ }^{2}$ Problematice těchto proticírkevních provinění se věnuje následující samostatná podkapitola.

\section{Zločiny ,proti církvi“"}

Na počátku období principátu se začala objevovat nová náboženství, pokud se zaměříme pouze na křest'anství, lze konstatovat, že až do počátku čtvrtého století našeho letopočtu čelilo mnohým perzekucím. Důvody byly různé, podle Olgy Tellegen-Couperus mohlo jít bud' o určitou uzavřenost vůči ostatním náboženstvím či o povídačky, které se mezi římskou společností šírilily a hovořily o skandálních křest’anských rituálech. ${ }^{53}$

K zásadní změně ve prospěch křest'anství pak přispěl Edikt milánský z roku 313 n. 1., který umožnil úplnou svobodu křest’anského vyznání. ${ }^{54} \mathrm{~V}$ následujících desetiletích důležitost církve jen stoupala, a na konci čtvrtého století je křest’anství možné označit za svým způsobem ,státní náboženství“، 55

Prvotní předpoklad, tedy že by bylo zločiny proti náboženství možno nalézt v Codex Theodosianus, se ukázal lichým. Respektive bylo zjištěno, že se v něm nenachází ustanovení, která by (byt' vzdáleně) odpovídala článkům v Æthelberhtově zákoníku.

Co se ale dalších zločinů proti církvi týče, není jich př́liš. Nelze však opomenout sacrilegium, tedy svatokrádež, jejíž pojetí a definice se v průběhu století měnily. Obecně ji lze vymezit jako „odcizení posvátných předmětů (res sacrae i res religiosae) [...] později jako různé trestné činy poškozující společnost" ${ }^{56} \mathrm{v}$ době pozdního císařství se sacrilegium rozšírilo a bylo vnímáno jako „,bezbožný čin vůči křest’anské víře“. 57

Pokud se rozhodneme držet definice svatokrádeže jako odcizení křest'anských předmětů, domnívám se, že vzdáleně př́ibuzný by mohl být například hned první článek

\footnotetext{
48 Ethelberht's code (Abt), op. cit.

49 Tamtéž.

50 Tamtéž.

51 Tamtéž.

52 Tamtéž.

53 TELLEGEN-COUPERUS, O. Titul: A Short History of Roman Law. [online]. London and New York: Taylor \& Francis e-Library, 2003, s. 122. Dostupné na: http://search.ebscohost.com/login.aspx?direct=true \&AuthType=ip,shib\&db=nlebk\&AN=460118\&lang=cs\&site=eds-live\&scope=site. [cit. 15. 4. 2021].

54 Tamtéž.

55 Tamtéž, s. 131.

56 BARTOŠEK, M. Encyklopedie řimského práva. 2. přeprac. vyd. Praha: Academia, 1994, s. 241.

57 Tamtéž.
} 
Æthelberhtova zákoníku, jenž hovoří o dvanáctinásobné kompenzaci za majetek Boha a církve. ${ }^{58}$ Jak bylo zmíněno výše, je to nejvyšší „násobek“, na který se podle kentského zákoníku kompenzuje, a je tedy velmi dobře vidět důležitost této oblasti, obzvlášt', když se hovoří o odcizení posvátných předmětů.

Sacrilegiem se okrajově zabývají i Digesta, v knize čtyřicáté osmé se říká následující: „Ti, kdož spáchali svatokrádež čeká nejtvrdší trest. 1. Svatokrádež je spáchána těmi, kdo vyrabují posvátné věci ve veřejném vlastnictví. Naopak osoby, které se pokusí ukrást posvátné věci v soukromém vlastnictví či z drobných svatyní, které nejsou stráženy, si zaslouží tvrdší potrestání než (obyčejní) zloději, ale mírnější než ti, kdož spáchali svatokrádež. Z tohoto důvodu musíš pečlivě uvážit povahu posvátné věci a tedy to, zda tento čin způsobuje obžalování ze svatokrádeže. “59

Při zapojení představivosti by bylo tento fragment možné vypozorovat v prvních pěti článcích Æthelberhtova zákoníku. V případě, že bychom na majetek biskupů, kněží či jáhnů nahlíželi jako na posvátné věci v soukromém vlastnictví, je možné sledovat určitou analogii s justiniánskými Digesty. Za krádež majetku těchto církevních hodnostářù totiž byly ukládány různě odstupňované pokuty. U biskupů šlo o jedenáctinásobek, u kněží o devítinásobek a u jáhnů o šestinásobek, zatímco již na počátku této kapitoly zmíněný majetek Boha a církve byl kompenzován právě na dvanáctinásobek. Nejedná se sice o trest smrti, o kterém podle mého názoru hovoří Digesta, přesto je ale trestem $\mathrm{v}$ této oblasti nejpř́ísnějším. ${ }^{60}$

\section{Lex Salica a francký původ Ethelberhtova zákoníku}

Navzdory názvu samotného článku a hlavní výzkumné otázce byly během výzkumu pramenů a literatury nalezeny výrazné podobnosti mezi Æthelberhtovým zákoníkem a Lex Salica, kterým se tato kapitola bude detailněji věnovat. Jak píše Karel Schelle, sálský zákoník byl zřejmě prvním franckým zákoníkem. ${ }^{61}$ Přesná datace jeho vzniku není známá, ale předpokládá se, že byl pořízen v době vlády krále Chlodvíka, tedy mezi lety 482 a 511 n. $1 .{ }^{62}$

Nabízí se otázka, jak se francký zákoník dostal až do království Kent, přičemž spatřuji dva stěžejní aspekty, které k tomu mohly napomoci:

1. Království Kent se nacházelo v jihovýchodním cípu Anglie, v těsném sousedství kanálu dnes zvaného La Manche. Naopak přes vodu, na území dnešní Francie se rozkládala Francká říše. Už jen tato bezprostřední blízkost by nasvědčovala možným obchodním či diplomatickým vztahům mezi oběma útvary.

2. Důvodem, který je ale dle mého názoru tím hlavním, byla však osoba manželky krále Æthelberhta. Tou byla dcera merovejského krále Chariberta I., princezna Berta. ${ }^{63}$ Tímto sňatkem se vazby mezi Franckou říší a královstvím Kent musely prohloubit. Domnívám se, že Æthelberhtův zákoník je toho důkazem.

\footnotetext{
$58 \quad$ Ethelberht's code (Abt), op. cit.

59 D. 48, 13, 11pr.-1 (Paul. l.S. de iudic. publ.).

60 Æthelberht's code (Abt), op. cit.

61 SCHELLE, K. - KADLECOVÁ, M. - VESELÁ, R. - VLČEK, E. - VOJÁČEK, L. - ŽIDLICKÁ, M.

Právní dějiny. Plzeň: Vydavatelství a nakladatelství Aleš Čeněk, 2007, s. 226 a 233.

62 Tamtéž, s. 233.

63 MATTHEW, D. Svět středověké Evropy: kulturní atlas. Praha: Knižní klub, 1996, s. 58.
} 
Následující část této kapitoly se věnuje porovnání některých článků z Lex Salica s Æthelberhtovým zákoníkem. Rozsah tohoto článku bohužel nedovoluje popsat úplně všechny, rozhodla jsem se tedy pouze pro některé vybrané, a to v následujících oblastech: krádeže spáchané otrokem, ublížení na zdraví, vražda a institut wergeldu. Pro lepší přehlednost jsem se v této části své práce rozhodla pro srovnání obdobných ustanovení využít tabulek.

\section{Krádeže spáchané otrokem}

\begin{tabular}{|l|l|}
\hline Lex Salica & Æthelberhtův zákoník \\
\hline „1. Pokud otrok mimo dům ukradne něco & „Pokud otrok provede ozbrojené přepadení \\
v hodnotě dvou denárů, měl by kromě zapla- & na silnici, měly by být zaplaceny 3 šilinky. \\
cení ceny ukradené věci a pokuty za zpoždění & (Článek 82)“65 \\
být natažen a mělo by mu být uštědřeno & „Pokud otrok krade, zaplatí dvojnásobek jako \\
120 ran. & kompenzaci. (Článek 83)“66 \\
$\begin{array}{l}\text { 2. Ale pokud ukradne něco v hodnotě } 40 \text { dená- } \\
\text { rů, bude bud' vykastrován, nebo zaplatí } 6 \text { šilin- } \\
\text { ků. Náhradu škody a pokutu z prodlení žalobci } \\
\text { ale zaplatí pán otroka, který krádež spáchal.“64 }\end{array}$ & \\
\hline
\end{tabular}

V tomto konkrétním prŕípadě lze pozorovat určitou podobnost, ačkoliv Lex Salica je výrazně detailnější, at' už v popisu hodnoty ukradené věci či trestu, který provinilého otroka za jeho čin čekal.

\section{Ublížení na zdraví}

\begin{tabular}{|l|l|}
\hline Lex Salica & Æhelbertův zákoník \\
\hline „Pokud člověk uhodí jiného člověka do hlavy & „Pokud dojde k poškození venkovního hionu \\
takovým způsobem, že je odhalen mozek a tř̌i & (s největší pravděpodobností kůže, co zakrývá \\
kosti, které leží nad ním, má být odsouzen & lebku), zaplatí 10 šilinků. \\
k zaplacení 1200 denárů, což činí 30 šilinků.“67 & a. Pokud dojde ke zlomení i lebky i vrstvy ji \\
„Pokud se rána objeví mezi žebry či v břiše & zakrývající, zaplatí 20 šilinků. (Článek 36)“69 \\
a dosáhne vnitřností, pachatel má být odsouzen & „Pokud dojde ke zranění břicha, zaplatí \\
k zaplacení 1200 denárů, což činí 30 šilinků & 12 šilinků \\
navíc k poplatku 5 šilinků pro lékaře.“68 & a. Pokud je břicho probodnuto naskrz, dostane \\
& 20 šilinků. (Článek 62)“70 \\
\hline
\end{tabular}
s. 178. Dostupné na: https://archive.org/details/selecthistorical00hendiala/page/n7/mode/2up. [cit. 17. 3. 2021]. 
Æthelberhtův zákoník se ublížení na zdraví věnuje velmi podrobně, z celkem 83 ustanovení se jej týká téměř polovina, konkrétně je to 38 článků. Kazuistika je zde detailní, specifikuje se, jaká náhrada škody bude např́klad zaplacena za konkrétní useknutý prst na ruce (za palec 20 šilinků, za „střílející prst“ tedy ukazováček 9 šilinků, za prostředníček 4 šilinky, za prsteníček 6 šilinků a za malíček 11 šilinků) ${ }^{71}$ nebo za probodnutí stehna. V tomto případě se ještě rozlišuje šíře rány, když byla širší než jeden palec, pokuta činila 1 šilink, pokud než dva palce, pak musel provinilý zaplatit 2 šilinky, v případě více než trrípalcové rány potom šilinky $3 .^{72}$

Jak je na první pohled vidět z prríkladů uvedených výše, oblast ublížení na zdraví se v obou pramenech v mnohém shoduje. Vždy se jedná o podrobný popis zranění spolu s kompenzací, kterou musí provinilá strana uhradit. Liší se množství detailů, které oba zákony poskytují, Lex Salica obecně zachází více do podrobností. Zároveň je zajímavé pozorovat, že některé typy zranění se vyskytují v Æthelberhtově zákoníku, ale už se nevyskytují v Lex Salica, a naopak. Např́klad kentský předpis popisuje sankce za poškození pohlavního orgánu:

„Pokud člověk poškodí pohlavní orgán, zaplatí cenu za tři osoby

a) Pokud ho probodne, zaplatí 6 šilinků

b) Pokud do něj bodne, zaplatí 6 šilinků. “"73

Lex Salica hovoří např́klad o použití otráveného šípu:

„Pokud člověk chce jiného zasáhnout otráveným šípem, a šíp mine, a jeho úmysl je mu prokázán, má být odsouzen k zaplacení 2500 denárů, což se rovná 63 šilinkům.“74

\section{Vražda a wergeld}

\begin{tabular}{|l|l|}
\hline Lex Salica & Æthelberhtův zákoník \\
\hline „Pokud je něčí otec zavražděn, synové obdrží & „Pokud člověk zabije svobodného muže, \\
dohromady polovinu peněz, druhou polovinu & zaplatí 50 šilinkủ králi jako odškodné za zabití \\
obdrží nejbližší příbuzní ze strany matky i otce & poddaného (lord-payment). (Článek 12)“ \\
a rozdělí si peníze mezi sebou. & „Pokud sluha zabije jiného nevinného sluhu \\
Pokud nejsou žádní prríbuzní, a to ani na straně & zaplatí jeho pánovi celou cenu. (Článek 79)“ \\
otce, ani na straně matky, tato část by měla být & \\
dána do veřejné pokladny (fisku).“75 & \\
\hline
\end{tabular}

Jak bylo uvedeno výše, institut wergeldu hrál zcela zásadní roli v obou zákonících. Během výzkumu primárních zdrojů bylo však zjištěno, že Lex Salica slovo wergeld neužívá. Článek LXII, který se věnuje náhradám za usmrcení, se v originálním latinském znění označuje jako De conpositione homicidii, ${ }^{76}$ tedy v doslovném překladu „O kompenzaci

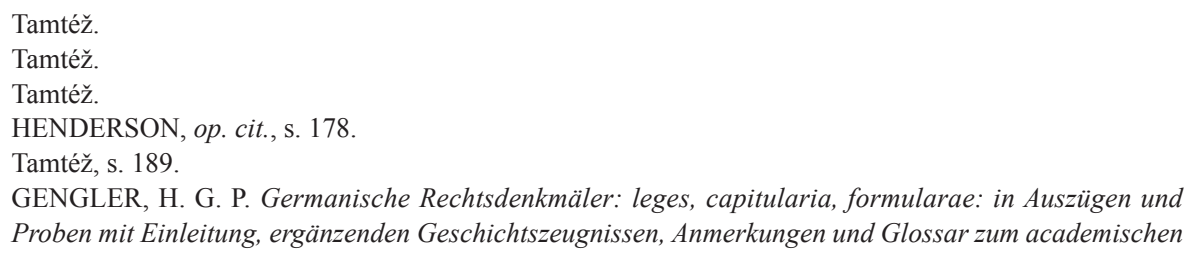


za vraždu“. Naopak anglický překlad, se kterým jsem také pracovala, užívá spíše překlad volný, a stejný článek označuje jako Concerning Wergeld, což lze přeložit jako „O wergeldu“.

Jde spíše o terminologickou zajímavost, ale v anglosaském prostředí se s termínem wergeld pracuje již od Æthelberhtova zákoníku, kde je konkrétně zmiňován v článku 31 . Tento článek nehovoří o vraždě, ale o cizoložství: ,, Pokud svobodný muž ulehne s ženou jiného svobodného muže, nechte ho vykoupit ji za jeho/její wergeld, sehnat za své peníze novou ženu podvedenému manželovi a přivést mu ji domů. “77 Dá se tedy říct, že se podle výše uvedené definice jedná skutečně o cenu, která byla každému člověku stanovena a řídila se také jeho společenským postavením.

Na rozdíl od Lex Salica Æthelberhtův zákoník není natolik pregnantní, aby uvedl, kdo a přesně v jakém poměru má wergeld obdržet. Článek 12 sice hovoří o platbě odškodného králi za zabití poddaného, jinak bychom ale tyto specifikace hledali marně. Æthelberhtův zákoník je pouze výčtem pokut za zabití osob v různém postavení, nikoliv ale toho, komu se peníze skutečně mají platit. Lze tedy pozorovat určitou odlišnost.

\section{Závěr}

Na několika málo stranách se tento článek snaží o identifikaci římskoprávních kořenů raného anglosaského zákonodárství, a to za pomoci komparace právních pramenů. Během primárního výzkumu bylo zjištěno, že lze nalézt velmi výraznou podobu mezi Æthelberhtovým zákoníkem a sálským právem, zatímco římské právo jako takové sloužilo pouze jako jakási inspirace. Např́klad v Digestech nebylo možno nalézt téměř žádná odpovídající ustanovení. Naopak např́íklad justiniánské Instituce či Lex Duodecim Tabularum se v některých ohledech shodovaly, nebo bylo alespoň možné nalézt jasnou souvislost mezi oběma porovnávanými prameny.

Co se Lex Salica týká, některá ustanovení jsou prakticky totožná s ustanoveními (či lépe řečeno články) kentského zákoníku. Původní výzkumná myšlenka týkající se římskoprávních kořenů byla touto prací vyvrácena, naopak bylo zjištěno, že Æthelberhtův zákoník má kořeny zejména v právu barbarských kmenů na kontinentu. Vzhledem k úzkému propojení francké říše a kentského království není s podivem, že k tomuto vlivu došlo. Samotná osoba královny Berty, manželky Æthelberhta a zároveň francké princezny, je dostatečným vysvětlením toho, jak se do Kentu Lex Salica mohl dostat. Vzhledem k tomu, jak Æthelberhtův zákoník ovlivnil další vývoj anglosaského právního systému, je velmi podstatné najít také jeho starší kořeny, o což se tento článek rovněž pokusil.

Samotný kentský zákoník, jak bylo zjištěno během primárního výzkumu, byl výrazně ovlivněn křest'anstvím, což lze pozorovat už v jeho samotném úvodu. Je zde totiž stanoveno, že byl sepsán v době převora Augustina. Ustanovení věnující se zločinům proti Bohu a církvi ovšem není možné naleznout ani v sálském právu, ani v Codex Iuris Civilis či v Codex Theodosianus. Kentský zákoník je tedy unikátní i svým zaměřením právě na tento typ deliktů. Je nasnadě, že do vzniku zákoníku zasahoval jak převor Augustin, tak i tehdejší papež, Řehoř Veliký, který byl obeznámen s Justiniánovým zákonodárstvím. Díky jeho

Gebrauche. Erlangen: Verlag von Andreas Deichert, 1875, s. 301. 
vlivu se do Æthelberhtova zákoníku nejspíše dostaly jak články týkající se křest’anství, tak články, jejichž inspiraci lze vypozorovat v římském právu.

V př́padě Æthelberhtova zákoníku došlo k aplikaci dvou druhů recepce podle typologie představené v samotném úvodu článku, a to k recepci coby přejímání práva, stejně jako k inspirační formě recepce. První z uvedených je relevantní pro převzetí struktury a téměř doslovné přijetí některých ustanovení Lex Salica, zatímco inspirace může být sledována spíše u římského práva, nebot' bylo relativně náročné naleznout totožná ustanovení. Citát Bedy Ctihodného, kterým je tento článek uveden, by tak zasloužil drobnou úpravu. Æthelberhtův zákoník nebyl napsán podle rrímského vzoru, ale podle vzoru franckého. Abychom tedy Bedovu citátu dodali na kredibilitě, bylo by jej třeba přepsat do následující podoby: Æthelberhtův zákoník byl napsán nikoliv juxta exempla Romanorum, ale spíše juxta exempla Francorum. 